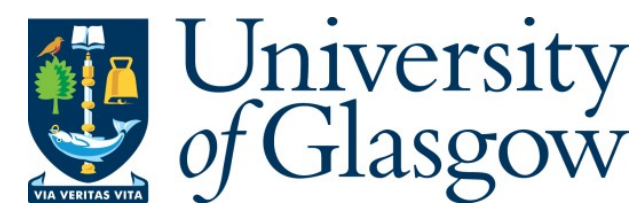

Selfe, M. (2013) Reading the geographies of post-war British film culture through the reception of F rench film. New Review of Film and Television Studies, 11 (4). pp. 455-476. ISSN 1740-0309

Copyright @ 2013 Taylor and Francis

A copy can be downloaded for personal non-commercial research or study, without prior permission or charge

Content must not be changed in any way or reproduced in any format or medium without the formal permission of the copyright holder(s)

When referring to this work, full bibliographic details must be given

http://eprints.gla.ac.uk/861497/

Deposited on: 23 J anuary 2014

Enlighten - Research publications by members of the University of Glasgow http://eprints.gla.ac.uk 
Title: Reading the Geographies of Post-war British Film Culture through the Reception of French Film

Author: Melanie Selfe, Lecturer, University of Glasgow.

Email: melanie.selfe@glasgow.ac.uk

Postal Address: CCPR, College of Culture and Creative Arts, University of Glasgow, G12 8QQ.

Tel: $+44(0) 1413302288$

Fax: $+44(0) 1413304142$ 


\title{
Reading the Geographies of Post-war British Film Culture through the Reception of French Film
}

\begin{abstract}
This article examines the ways in which British specialist film culture anticipated and received the resumed supply of French films at the end of the Second World War. It finds that in serious film journalism and within the rapidly expanding film society movement, new French cinema was the focus of at least as much British attention as Italian neo-realism - the European cinema more famously associated with the era. The article posits that a number of factors, including anti-Americanism, combined to position the delayed wartime and immediate post-war French releases as a site of impossible expectations and subsequent interpretative difficulty for British cinephiles. In particular, through a case study of the local mediation of French cinema in the English city of Nottingham, this article considers the role of published criticism for setting the local viewing frame within the provincial film society movement. By tracing the tensions surrounding the circulation of film prints, information and opinion relating to these prestigious cultural imports, it becomes possible to gain greater insight into both the range of nationally specific meanings attributed to the imported films and the geographic and cultural inequalities at work within the film culture of the country of reception.
\end{abstract}

\section{Keywords}

film society movement; transnational reception; film criticism; French film; post-war film culture

\section{Introduction}

Reflecting on over a hundred years of the international circulation of cinema, Dudley Andrew has suggested that our experience of film is always multiply marked by 'delay and slippage'. He argues that cinema is inherently temporally and spatially 'out-of-phase with itself', and turns to French to find a term - décalage - that he feels encapsulates the idea of this gap at every scale: from the individual viewer's physical journey to the cinema and experiential journey through the film to the networks of international distribution and intellectual exchange that enable previously unheralded national cinemas to be incorporated into the expanding 'world' canon (2010, 62-3).

However, working through the five overlapping phases that Andrew identifies in the development of 'world cinema', it is striking that the flows, new recognitions, 
cultural longings and time-lags he outlines take place at the level of the national via the activities of an evolving elite of internationally connected, mobile individuals: journalists, critics, festival programmers, filmmakers and academics. There is, of course, never one version of world cinema but multiple versions simultaneously visible from a potentially infinite range of geographic, temporal and cultural points. Andrew's chapter concludes with the insightful assertion that films which travel from their own place and time 'reach viewers elsewhere, all situated differently, all out of phase with themselves and each other' $(2010,86)$. Nonetheless, due to the reliance on canonical published sources, such as Cahier du Cinema, he inevitably reproduces the standard international aesthetic film history of the post-war period, even as he critiques it. In order to understand the slippages and time-lags that lie between the procession of national cinema discoveries famously feted at Cannes and Venice and subsequently consolidated within the narratives of film studies and the individually and historically situated viewer, who sought out and engaged with foreign films within her or his own national and local context, examination of a wider range of published and unpublished sources is required.

To this end, this article deploys a detailed case study of the screening and critical framing of French cinema in a provincial film society in post-war Britain. The Nottingham and District Film Society (henceforth N\&DFS) was founded in 1945, and aimed to provide the citizens of this mid-sized city in the English East Midlands with their first regular access to foreign and cultural films. Dedicated to fostering film appreciation, it was typical of the post-war expansion of the British film society movement in its Eurocentric programming practices, humanist outlook and pointed apoliticism (Selfe 2007). But as the number of British film societies mushroomed from around 20 in 1944 to over 200 in $1949,{ }^{1}$ the supply of films failed to keep pace with the published debates and growing local interest. Therefore, attending to both national critical reception and locally produced materials - including programme notes, administrative records and member request slips - this article examines the ways in which the stuttering flows of advance information, critical opinion and film prints worked to magnify existing geographic inequalities of cultural authority. Through the gaps that emerge between the conflicting British versions of French film, it becomes possible to address territorial battles for British film culture.

In taking this approach, this study builds upon but also adapts and extends several existing strands of research. Authors working from national cinema perspectives have demonstrated that historical reception studies can uncover forgotten transnational engagements, as Sarah Street (2002) and Leila Wimmer's (2009) books have done for our understanding of the presence of British films within American and 
French culture respectively. In this article, however, I am guided by the preoccupations of the historical audience. Therefore, it is their screening practices and discursive focus that determine my selection of which national cinema to attend to. In this respect, I add to a growing body of reception and audience centred work tracing the exhibition, publicity and popular discourse surrounding foreign films. Authors such as Douglas Gomery (1992, 171-195), Barbara Wilinsky (2001), Mark Betz (2003), Mischa Barr (2009) and Lucy Mazdon (2010) ${ }^{2}$ have started to map the national specificity of the cultural reception of the predominantly 'continental' foreign cinemas that were in circulation in post-war Anglophone contexts, expanding our understanding of both the range of films screened and the ways in which they were presented. These studies counter the dominant art-focused narrative of European cinema by positioning foreign films as another commercially framed viewing option. They argue that the growth in the popularity of European films during the 1950s was less driven by a widespread concern with cinema as a noble art than by a mixture of aspirational cultural consumption and the salacious promise of sexual content. However, whilst an important corrective, this revisionist approach underplays the degree to which there really was a popularisation of intellectual engagement with cinema during the post-war era and the part foreign films played within this. Moreover, although many of these studies draw on geographically specific, nonmetropolitan examples, they still seek to build national accounts of critical interpretation or commercial presentation, rather than exploring the internal geographies of access, framing and potential meaning.

A different body of work has begun to map the intellectual history of film culture and the gradual emergence of formal film study through a focus on key institutions and pedagogic practices (Acland 1994; Wasson 2005; Dupin 2006; Polan 2007; Grieveson and Wasson 2008; Bolas 2009). This article will contribute to this picture, but in selecting a provincial film society that could be considered a follower rather than a leader in its field, I also acknowledge a debt to the decentred approach to historical audiences developed by Robert Allen and Douglas Gomery (1985), Gregory Waller (1995), Kathryn Fuller-Seeley (2008) and others, including one study specifically addressing the film culture of Nottingham itself (Jancovich 2003). This work has asserted the importance of understanding the 'Main Street' experience of popular cinema over the dominant but inherently exceptional metropolitan narrative. In applying these 'ordinary' priorities to what is usually considered a more highbrow topic, I am attempting a deliberate shift of emphasis in the history of intellectual and cinephile film culture. A number of studies have sought to map the points of origin and international circulations involved in the development of the most aesthetically and politically radical aspects of film culture during the inter-war years, a period 
Malte Hagener has framed as 'the first wave of cinephilia' (2007, 77; See also Hogencamp 1986; Marcus 2007; Sexton 2008). In contrast, here I aim to explore the processes of transmission and mutation involved in the national articulation and local domestication of a serious approach to cinema, a process that began in the UK within the provincial cultural film societies of the 1930s, but which blossomed in 1945, at the start of a period we might consider cinephilia's second wave.

A grounded and nuanced understanding of the values of this facet of British film culture is necessary because, although never revolutionary, this loose post-war alliance of quality critics, national organisations and voluntary groups were quietly influential. Through practices of programming and informal pedagogy, ultimately consolidated through the establishment of a network of Regional Film Theatres, they disseminated enduring interpretative habits and helped to shape the terms on which 'quality' and cinephile film taste would be defined in Britain for many years to come (MacDonald 2012; Selfe 2012).

\section{The film society movement, film criticism and the dynamics of serious film culture}

The five years following the war saw British interest in foreign and overtly cultural cinema expand beyond the usual metropolitan and major urban centres. While this paved the way for the widespread British commercial exploitation of continental films in the 1950s, this initial wave of post-war interest framed imported films considerably more soberly, as 'serious' or 'specialist' cinema. Foreign films were presented as authored art, the best of which were seen to simultaneously express both unique national characteristics and common humanity. One driver of this approach was a crusading style of film criticism that had gathered momentum during the 1940s and which sought to both raise the cultural status of film and improve the nation's cinematic tastes (Ellis 1996). Another related factor was the rapid growth of the film society movement. Facilitated by the new booking services developed by a rejuvenated British Film Institute (henceforth BFI) and the British Federation of Film Societies, this membership-based voluntary movement provided access to foreign and cultural cinema within a strongly educational framework (MacDonald 2012).

Andrew positions the film clubs and societies that blossomed across Europe within the immediate post-war period as part of a loose network of 'united communities', a facet of a broader wave of 'federated' thinking arising in response to the war. However, whilst the N\&DFS subscribed to the goal of using film to foster universal understanding, its ability to engage with the other ideals of federalism was 
limited by the fact that local imagining of and access to foreign cinema was strongly mediated through both the national and the metropolitan. Where Andrew speculates that the regionalism embedded in the federal ideal would support 'equality and difference' within film culture, empirical evidence paints a more conflicted picture. Serious film culture in Britain was still deeply engaged with the inter-war issues of sustainable national film production, and throughout the war various commentators had come to see the film society movement as integral to this: a key means of improving the quality of national film taste by changing the nature of spectatorship and thus, ultimately, reforming consumer demand (MacDonald 2012, 88). Consequently, anxieties over what Andrew terms 'national tardiness or prescience' (Andrew 2010, 66) applied equally to British films and to British filmgoers, and shaped the discourse about which foreign films were considered to be of value.

In framing the dynamics of power involved in specialist film culture, it is essential to stress the disproportionate importance of film criticism for serious cinema audiences. From the 1920s onwards the film society movement and serious writing about film had developed hand in hand, each fuelling the other, and after the end of the war a host of new titles appeared to cater to the growing film society market. Reading about film was absolutely central to the type of 'film appreciation' that the British film society movement fostered. This can be seen in the way that the views of published critics were presented to members by various film societies. From 1948 onwards, members of the N\&DFS had access to a small private library of books and journals, held in a bookshop located between the city centre and the cinema venue (N\&DFS Programme Notes, 18 December 1949). This collection included titles by Forsyth Hardy, Siegfried Kracauer, C.A. Lejeune, Ernest Lindgren, Rachel Low and Roger Manvell, and Nicole Vedrès. Periodical holdings included the Penguin Film Review; Documentary Film News (formerly Documentary News Letter); Hollywood Quarterly; Film Forum; Cinèas; the BFI's two publications, Sight and Sound and The Monthly Film Bulletin; and a few issues of Sequence. As Richard MacDonald highlights, Roger Manvell was a particularly important voice (2012: 87). He edited the Penguin Film Review, wrote regularly for the BFI's flagship publication, Sight and Sound, and advocated both film appreciation and the virtues of film societies through his bestselling 1944 Pelican paperback, Film.

However, some of the most influential writers were the critics who wrote regular columns for the national press. As Ellis has explored, during this period the 
writers who reviewed films for the quality dailies and weeklies promoted a critical agenda based on cultural uplift (1996). They were not in tune with the preferences expressed by the majority of filmgoers at the box office, but they shared the realist tastes and humanist values of the film society movement. However, while critical opinion mattered to many dedicated filmgoers, provincial film society programme writing practices worked both to increase the number and magnify the importance of the published critical voices encountered before the viewing experience.

The practical case for providing audiences outside London with a critical round-up was made by Ena Knight, when the Birmingham Film Society Film Guide was launched in 1946. This newsletter was initially intended to give the film society a presence in the city during a period when it lacked a venue, but it soon developed into a substantial monthly undertaking, collating information about local screenings and presenting them in conjunction with selected print reviews of the films. ${ }^{3}$ These reviews had been gathered from the national press at the time of their London releases and Knight proposed that without such an aid the Birmingham member might miss good films 'because he didn't know they were being shown locally or, after the unfortunate time lapse between London and Birmingham showings, had forgotten his favourite critic's comments' (Birmingham Film Society 1948, 16).

In stressing that members might have a particular reliance on an individual critic, felt to be in tune with their own taste, Knight highlights place of key critics as personal role models for critical practice. However, through the juxtaposition of multiple views, such round ups provided more than just the chance to refresh the viewer's memory of a review encountered over breakfast many months previously. In the hands of film society programmers, quotes from published reviews became pedagogic tools. In Nottingham, the film programmes posted to members in advance of each monthly screening combined published criticism with original text, remediating both the foreign films and the debates surrounding them for the local membership.

\section{Film criticism and the post-war appetite for foreign film}

Between the outbreak of war in 1939 and the autumn of 1946, New London Film Society co-founder Rodney Ackland observed that, 'the international circulation and 
exchange of classical films was practically impossible' (1946). However as the war drew to a close, optimistic critical attention turned to the renewed availability of new foreign films. Film-centered histories usually position Italian neo-realism as the key creative postwar departure in film style to emerge during this period. As various writers have observed, neo-realist titles - frequently dubbed rather than subtitled helped to take foreign film beyond its usual audience and increased the commercial viability of continental film exhibition (Wilinsky 2001; Barr 2009). However, rather less convincing is David Bordwell's argument that it was the first of a series of aesthetically innovative and challenging post-war art-house film 'waves' that drove viewers to seek realist motivation and authorial intent in response (2002, 98. First published 1979). As Janet Staiger has argued (1992), in the context of the American reception of neo-realism, there was an existing American discourse surrounding 'serious' film, which mobilised directorial authorship as an interpretative tool substantially before the arrival of the types of 'ambiguous' European films that Bordwell suggests demanded it $(2002,98)$. Consequently, Staiger argues that the invocation of Rossellini's signature by critics, on the American release of Open City (Rossellini, 1945), was in keeping with the established practice of attributing films with social 'messages' to director 'senders', rather than a novel response to an advance in film form (Staiger 1992, 182).

Although keenly anticipated by the British specialist audience, in keeping the American reception described by Staiger, Italian neo-realism presented these filmgoers with no great interpretative challenge. While some of the later arrivals contained so much sentiment and overt sexual display that self-consciously serious viewers began to question the coherence of Italian neo-realism as a category, the early entries, such as Vivere in pace (Zampa, 1947), Paisa (Rossellini, 1946), Open City, and the Bicycle Thieves (de Sica, 1949), delivered precisely the qualities that British specialist film culture already prized: documentary influenced aesthetics, gritty realism, a humanist perspective and an authorial voice. For viewers well versed in British and European documentary forms, Italian neo-realism was considered surprising only in the respect that this socially conscious cinema had emerged from inside a fascist regime. Moreover, neo-realist discoveries delighted British specialist audiences, in part, because there were no significant national cinema expectations for Italian films to live up to. This was not the case for French cinema, however, for 
which British expectations were impossibly high.

To put this in context, firstly, it is important to consider the strong Francophile tendencies established within the British specialist film scene by 1945. French cinema had been by far the most commercially and critically successful foreign language cinema in the UK prior to the outbreak of war, with the range of films and exhibition venues prefiguring the larger scale post-war developments (Porter 2010). However, even when the war brought the closure of London's specialist cinemas and the suspension of many of the older provincial film societies, the link between film culture and French culture persisted. Critics lamented absence of new French films, and the reputations of the pre-war poetic realist titles grew, fuelled in part, as Mazdon notes, by regular wartime film society screenings $(2010$, 430). The St James Place headquarters of the New London Film Society - the inheritor of The Film Society's elite inter-war mantel (Sexton 2008) - was also the home of the French Club (or Le Petit Club Français). This club, run by Olwen Vaughan, ex-BFI staffer and the New London's founder and secretary, was a haven for French exiles and the fashionable intellectual film crowd throughout the war (Ackland and Grant 1954, 168-171; Drazin 1999; D.P., The Times 1973). The post-war British Federation of Film Societies also made a strong Francophile statement, when they used the Institut Français in London as the regular venue for their new annual viewing sessions. Moreover, as Emily Munro has explored, the BFI's flagship magazine, Sight and Sound, promoted the connection in explicit and implicit ways. The publication not only carried frequent reviews of French films and French publications about cinema, it also presumed readers' proficiency in French language through subtle wordplay in the jokes and cartoons $(2006,95-98)$.

In addition to these elements, there was a fresh factor in post-war audience expectation: a real desire to understand the French wartime experience. Interest in the cinematic outcome of this period of trauma and isolation was partly driven by the humanist and internationalist concerns of serious film culture, and writers speculated on the impact that Occupation and Resistance might have had on the sensibility and practice of French filmmaking. However, there was also a secondary reason; British writers entertained the possibility that, in spite of hardship, cultural isolation might have brought benefits as well as disadvantages. This idea was grounded in a much 
more nationalist outlook, fuelled by British fears that its own cinema and audiences had absorbed too many American influences.

The wish to comprehend various aspects of the impact of a nation's war experience on its film art runs through much of the seriously intentioned British film writing of the period. However, the relationship between the twin desires for cultural understanding and cultural protectionism can perhaps be seen most clearly within 'The Film in France', a fifty-page book/pamphlet by Roy Fowler, published by Pendulum Press in 1946. Fowler opened by declaring that 'There are moments in a nation's life, when by virtue of circumstances, a huge mass of the population veers in a certain direction' $(1946,2)$. In line with the reasoning of Seigfred Kracauer's soon to be published From Caligari to Hitler (1947), Fowler felt that the cinema, more than other media forms, had the ability to capture and reflect national sentiment. Having made a clear separation between the French cinema of great artists and the country's commercial industry, which he dismissed as producing films which were, 'if anything, worse than their American and English counterparts,' Fowler proceeded to outline why 'the best' of French cinema was so highly valued, before going on to ponder how the circumstances of war might have altered and even enriched it.

These pre war films of which we speak-from Sous les toits and La Chienne to La Bête Humaine and Le Jour se lève - were French films made for the world without losing any of their national characteristics. They were universal successes among people of all countries who brought a measure of attention to them since they were about people and events observed without pandering to any popular notions. (3).

Fowler attached great importance to the idea of the truthful capturing of national character. He believed that the absence of commercial motives had allowed French cinema to find its international audience, and having done so, had provided that audience with a direct insight into something essentially French. This argument echoed an earlier theme from the Sight and Sound of the 1930s. The publication had profiled many national cinemas and held French cinema up as the most inspirational national film culture: a suitable model for the British industry to emulate in order to produce films that were competitive in the international market by being distinctive on their own terms rather than by aping Hollywood in scale or style (Rose 1937, 72). Addressing the impact of war on French film, Fowler continued: 
With the Armistice of 1940, however, the position became completely reversed. In a few days, France became cut off from our world and influences and we from theirs. The broadminded French had only France to concentrate upon; British and American films were banned, German and Italian films were the only ones able in great measure to offer competition. It was inevitable that these conditions should greatly alter the nature of French films. We, the general public of Great Britain, for our part knew nothing of these changes, and during the past year we have only just been beginning to find out exactly what they meant. (3).

Fowler perceived the absence of American influence as contributing towards a less contaminated artistic environment for French film production. Considered against the backdrop of the necessary strengthening of cultural ties between Britain and America throughout the war, and the anxieties this caused for British critics, this absence should be understood as twofold: firstly the suspension of a directly negative influence on French audience tastes and filmmakers' ideas, and secondly the removal of the temptation to court a potentially lucrative US market.

For Fowler this leads to a very positive, if somewhat uncritical, interpretation of French wartime films. He presumes German and Italian films to be an unwanted intrusion and therefore not an influence that would be absorbed; interprets many films as responding to the presence of Occupation forces in a resistant, if camouflaged, way; and considers even the productions made by the Vichy/German financed company, Continental, to be benign and 'completely lacking in propaganda'(1946, 7).

In presenting the possibilities of post-war French film to the reader, Fowler played on the mystery of the situation, positioning himself as mediator of their meaning. He argued that 'the best of the new French school will seem strange and puzzling to British eyes' and that, although this strangeness needed no excuses, explanations were in order. In his attempt to provide these, Fowler surveyed the field and divided the new films into two categories: the 'realist' which followed the prewar tradition he valued so highly, and the 'poetical' which he claimed to be a 'wholly French' development from this tradition, and a 'direct product of the war'. This new category, he claimed, attempted to 'convey subjective feelings by objective means', and bordered on the territories of myth, poetry and fairy story $(1946,19)$.

Fowler was not the first to propose this kind of dual categorization in print. Sight and Sound had begun its spring 1946 issue with a survey by Hazel Hackett of 
'French Cinema During the Occupation.' This detailed the difficult conditions of production, building the myth of art from adversity (1946a). This was followed up in the summer issue with her account of 'French Cinema Since the Liberation.' In this, she noted that 'apart from the resistance films, it is hard to find any particular tendency in recent French films.' Where Fowler had found the turn to the fantastic to be uniquely French, Hackett situated it within a wider trend for supernatural narratives in British and American films, suggesting this the recurrence of 'other worlds' was driven by the human losses of war (1946b).

In spring 1946, Sight and Sound had followed Hackett's first piece with a companion article by Roger Manvell, focusing on one of the directors in question and a key figure in Fowler's book: Marcel Carné. Manvell outlined Carné's critical reputation in Britain prior to the war, highlighting the fact that, through the work of the film society movement, recognition of the director had extended beyond London. He then proposed Carné's last pre-war work, Le Jour se lève (1939), as a perfect exemplar of the nation's cinematic art:

(A) masterpiece in the true tradition of the best French cinema, which combines rich human characterisation supported by unusually fine acting with the quality called realism. This realism implies faithfulness to the true situations and emotional reactions of human life together with the careful reconstruction of background and the atmosphere of locality. (4).

Manvell then proceeded to review the director's two wartime productions, Les Visiteurs du soir (1942) and Les Enfants du paradis (1944). He expected most of the Sight and Sound readership would already be familiar with their titles, and related these new 'nostalgic' 'evocative' historically set films to Carné's pre-war work: Le Quai des brumes (1937), Hôtel du Nord (1938) and Le Jour se lève. These earlier films he classed as being marked by 'immediacy' and 'a sense of actuality' (5). Across all Carné's titles he managed to find kindred technique and meaning despite the superficial differences. However, although Manvell explained the past settings of Carné's wartime pictures as providing freedom of expression in a time of political oppression, he ultimately urged Carné to return to the present 'for it is in the contemporary idiom that French cinema has created its own form of poetry' (6).

Despite some differences in interpretation and in the precise use of the key terms 'realist' and 'poetic' by the different writers, there was a consensus that the war 
had produced a new type of French film, and that Carné was not its only exponent. Two of this new category, L'Éternel retour (Delannoy, 1943) and Carné's Les Visiteurs $d u$ soir, had received London screenings at the point that Fowler's book went to press; however, there were still many titles yet to arrive. As a result, both Fowler and Manvell's evaluations of the significance of the films of the 'new French school' preceded the ability of British audiences to come to their own conclusions about them.

This was not in itself unusual, but the combination of heightened anticipation and delayed availability visible in this instance served to magnify the power relationships that were (and still are) involved in the flow of information surrounding any film, and particularly any foreign title. Via writers who were in touch with foreign critics and filmmakers, there would be ripples of information about new releases and forthcoming productions. On the British scene, Manvell, Hackett, and Fowler, who wrote for the specialist interest market, had all clearly travelled to France to conduct research. Their respective book/articles, delivered an authoritative combination of information and opinion about French cinema, influenced by the debates taking place within France and providing a framework of expectation into which the British evaluations of individual films could slot.

The next ripple of opinion accompanied a film's London release. This was the point when a film was reviewed by multiple critics in the national press, and for those outside London it was also the point at which the inequality of access was most acutely felt. Prior to the national reviews, the problems of film availability were nationally shared; everyone was waiting for the films to arrive from France (or the USSR, Italy, Japan...). Once a film had arrived within London that dynamic shifted.

The N\&DFS not only aimed to screen the films of the world, it also sought to frame public discourses on cinema for an audience that was well behind London in the distribution circuit. In line with the broader movement, the film society constructed itself in opposition to the commercialism of Hollywood, and as such, had a great investment in mastering the terminology and discourses surrounding other national cinemas. However, as the first general film society in the Nottingham area it also needed to give its members a chance to catch up with the famous French classics which other film societies had been enjoying for several years. 
The first French film to be screened by the N\&DFS was La Kermesse héroïque (Feyder, 1936), a title that, until its revival and DVD reissue by the BFI in 2004, had all but fallen from the British version of the French classic cinema canon. This is curious, because for many years it was one of the most respected and most frequently revived titles. Billed as 'the sensation of Europe and America' and 'the world's most sensational film', it ran for six months at Studio One in the West End on its initial UK release. It then continued in suburban cinemas, before returning for a series of short London runs in late 1937, and was even aired on the fledgling medium of television in October 1938. ${ }^{4}$ In 1938, the members of the Tyneside Film Society voted it their most popular film of the season (Dyer 1938, 78), and it continued to be a top renter on the film society circuit. In 1950, fifteen years after its initial release, $11 \%$ of film societies (from a survey sample of 80 ) screened it (Sight and Sound 1950, 263), and the following year saw film societies wait impatiently for the release of a newer and more complete print.

The film is a satire with a rich period setting - beautifully produced and rather risqué. It tells the story of a seventeenth century Flemish city, fearing devastation and destruction from a Spanish battalion who are about to come to town. When the men fail to come up with a plan, the Mayor's wife takes charge, enlisting the other women, and creating a welcoming carnival, to charm the soldiers with traditional feminine wiles. In the Nottingham programme notes, the director Jacques Feyder is praised as a genius, and the local writer describes what is referred to as a sense of solidity: 'A feeling of authenticity which makes it difficult to realise that we are not right back in the middle ages, but actually in a cinema watching a studio reproduction.' Through this somewhat literal account of realism, the film is held up as the epitome of French film, and incontrovertible evidence that cinema is a real art form. Much of the film's achievement was put down to the way it alluded to Flemish painting; however, this formal referencing of older art forms was rather at odds with both the gritty realism of the urban set films that Manvell admired, and also with the more lyrical and fantastical interpretations of the past that were beginning to emerge at the end of the war. The film may also have begun to fall from favour for other reasons. Feyder, the film's director, had weathered the war in neutral Switzerland, unlike Carné, who was repeatedly being discussed in terms of courageous resistance. Furthermore, the film's message could be read as supporting collaboration. 
In many of his writings on the new French films Manvell expressed a clear preference for the contemporary setting, and although he was willing to make exceptions for the case of occupation, a general move back to period drama was seen as a retrograde step. Through his position as editor of the Penguin Film Review he enlisted other writers who would press this point forward. Nicole Vedrès, a French critic/filmmaker who was invited to be a regular contributor on French cinema, suggested that the time of Film d'art was - or by implication should be - over (1946, 78). William Novik, a filmmaker/critic from the more avant-garde end of the French scene, went further in his article 'Four Years in a Bottle' where he proposed that the combination of German money and the absence of creative competition had presented the French film industry with a precious opportunity. He argued that the Occupation had both reduced the interference of the producer, and advanced the primacy of the director over the scriptwriter, but concluded that the new freedom had been squandered: 'In full possession of this freedom, writers and directors went straight back to the Film d' art weighed down by bombast and affectation' $(1947,53)$. Novik held one post liberation production up as an exception and a beacon for the future La Bataille du rail (1941). This film shared some features with the new Italian neorealist developments: it was a film about the resistance made with a non-professional cast.

In championing the tougher realist films, the critics writing for the Londonbased publications were attempting a deliberate canonical shift, and as they tried to persuade people of what they ought to watch, they were not above playing to the audience's insecurities. In her article 'It's typically French' Nicole Vedrès (1948) lists La Kermesse hérö̈que, and particularly the work of the hugely popular Marcel Pagnol, as just the type of light charming fare which does well overseas, citing amongst others the 'psychological realism' of Duvivier's Pepe le Moko (1941), or Carné's Le Quai des brumes and Le Jour se lève, and anything by Vigo as far more indicative of authentic French taste. In this, she gives a clear incentive for those aspiring to be genuinely cosmopolitan rather than mere cultural tourists. She appeals to the reader's need to feel sophisticated, in order to guide the audience towards the French films she prefers, and which she would like to see used as the template for future French production. 


\section{Screening French Film in Nottingham}

La Kermesse héroïque was not the only one of the films screened by the N\&DFS that the critical elite might have considered a faux pas. From the outset, the society screened light French comedies as well as the older period set features that were now falling from grace - and they continued to do so as they waited for the new titles to become available. These included Fric-Frac (Lehman, 1939), 'a new and delightful anecdote' to add to the world of 'picaresque fantasy' (N\&DFS. 1947. Programme Notes, October 19), and La Femme du boulanger (Pagnol, 1938) in the 1947/48 season (N\&DFS. 1947. Programme Notes, November 30).

For all the Nottingham \& District's continued engagement with French comedy and costume drama, there was a difference in the language used to describe them. These lighter films were appreciated for their delicacy and wit, and for the enjoyable afternoon they offered, but the greatest praise was often lavished on the actors rather than the director. The La Femme du boulanger programme notes present a prime example of this. Through a quotation from the New Statesman, the film's star, character actor Raimu, is credited with lifting the film and 'giving it breadth and symbolism' (N\&DFS. 1947. Programme Notes, November 30). This enabled the prized quality of realism to be found within finely wrought performances and observational details, rather than attributed to the films as a whole. Sympathetic quotations were sourced from broadsheet reviewers to support the films, but these were often edited together in a way that both promised pleasure and warned the viewer not to expect too much in the way of 'greatness'. These films were not presented as being truly on a par with the great directorial masterpieces.

In December 1948 the N\&DFS programme notes included a film request slip. Forty-eight members returned them, requesting a (legible) total of 251 films between them. ${ }^{5}$ The table below shows how these preferences were distributed by nation of production.

\begin{tabular}{|l|l|l|l|}
\hline \multicolumn{3}{|l|}{ Members' requests received in the season 1948/49 for the following season } \\
\hline Nation & $\begin{array}{l}\text { No. of requests } \\
\text { received }\end{array}$ & $\begin{array}{l}\text { No. of films } \\
\text { requested }\end{array}$ & $\begin{array}{l}\text { Average no. of requests per film } \\
\text { title }\end{array}$ \\
\hline France & 119 & 43 & 2.77 \\
\hline Italy & 32 & 8 & 4 \\
\hline USA & 54 & 26 & 2.08 \\
\hline
\end{tabular}




\begin{tabular}{|l|l|l|l|}
\hline Germany & 22 & 8 & 2.75 \\
\hline GB & 9 & 8 & 1.13 \\
\hline USSR & 6 & 5 & 1.2 \\
\hline Switzerland & 3 & 2 & 1.5 \\
\hline Sweden & 2 & 2 & 1 \\
\hline Argentina & 2 & 2 & 1 \\
\hline Austria & 1 & 1 & 1 \\
\hline Czechoslovakia & 1 & 1 & 1 \\
\hline Total & 251 & 107 & 2.35 \\
\hline
\end{tabular}

Figure 6.1 N\&DFS Members' Film Requests by Nation

The most striking feature is that $47.41 \%$ of all the requests made were for French films; however, the individual film title attracting the highest number of requests was Italian: Paisà (Rosselini, 1946), with eleven votes. Where just a handful of much-discussed new Italian films attracted the majority of the votes for that country, the requests for French films were distributed over forty-three separate titles. Even beyond the denser concentrations of votes for the most debated films, new festival hits, and occasional pre-war favourite - Les Enfants du paradis (10 votes), Monsieur Vincent (Cloche, 1947) (9 votes), La Belle et la Bête (7 votes), Un carnet de bal (7 votes), Le Jour se lève (6 votes), Le Diable au corps (Autant-Lara, 1947) (6 votes) - that left many films, from the silent era to the most recent, which received just one or two votes. This demonstrated that within the membership there was simply a far greater breadth and depth of knowledge of French film than for any other nonEnglish speaking nation. Despite the absence of a dedicated specialist cinema in Nottingham at this time, the membership had enough familiarity, built through wider reading, cinema-going/film society attendance elsewhere, and occasional screenings at mainstream cinemas in the city, to have their own expectations and anticipations of French film.

As soon as availability permitted, the N\&DFS chose to screen a high proportion of French films. In the 48/49 season they finally managed to book some of Carné's newer titles and set about relating them to the now well-established debates. In the programme for the pre-war Le Quai des brumes they take the opportunity to explain that Carné's films fall into two categories, the realistic and the fantastic, and that Le Quai des brumes 'like Le Jour se lève is in the genre of poetic realism.' The notes proceed to outline the themes of these films and explain how the aesthetics lift the film above 'drab melodrama'. The notes then conclude by connecting the title to 
later screenings in the season, offering members 'the opportunity of contrasting this film with Carné's Les Visiteurs du soir made during the Occupation and which falls into the category of the fantastic' (N\&DFS. 1948. Programme Notes, October 3).

In this process, although the divided classifications established by Manvell and others are replicated, Manvell and the Penguin Film Review's underlying argument against the fantastic/historical setting is not. This is clearly a diligent effort to keep members up to date with the current cinematic and critical trends, and to illustrate commonly used terms with concrete examples, but it avoids prefiguring audience responses and potentially undermining attendance through negative comparisons. However, the following season, when screening the most anticipated and locally requested Marcel Carné release, Les Enfants $d u$ paradis, ${ }^{6}$ the N\&DFS took a more cautious tack.

Although the film had been generally well received on its eventual London release, it was three hours long and had disappointed some critics. Therefore the local programme notes were not only used to apprise members of existing debates; the framing also functioned to help members manage their expectation. To that end the programme for Les Enfants du paradis skilfully combined three conflicting reviews (N\&DFS. 1949. Programme Notes, October 2). The first and longest segment by the Edinburgh based Forsyth Hardy, writing in the Filmgoer's Review, placed the film within the context of other films of the Occupation and concludes: 'only a director of genius could so relate the parts to the whole as to make clear the size and significance of the theme. This is a film of stature not to be absorbed at a single viewing'. Next, the Observer's C.A. Lejeune's more personal response (as quoted) runs:

It seems to me to stand head and shoulders above every other film of the year ... I recommend it ... to anyone who relishes fine performance, exact dialogue, magnificent manipulation, and an honest, if fatalistic groping towards philosophy.

The final, most critical review excerpt came from the always-anonymous reviewer of The Times. Whilst acknowledging that there had been cuts made to the film, this writer felt that the film failed to deliver on the promise of the first half hour, despite the fact that it ran to three hours. Where Hardy had found it wholly successful in drawing together a vast array of elements, this writer thought it lacked form. And 
where Lejeune had described a perceived 'groping' as an honest attempt at philosophy, this reviewer charges the film with an 'inclination to tread heavily on the top of a dark staircase which is not there.' The positive reviews outnumber the negative, but within the negative quote, the same elements which the first two reviewers value are negatively interpreted. This created a consensus about the grounds on which local judgements should be made, providing members with the space to disagree and with templates for doing so. Crucially, however, the final quote prepares the viewer for the possibility that the film may amount to rather less than the sum of its well-publicised parts.

The N\&DFS drew willingly and heavily on the discursive models offered by professional film writing, but there was nonetheless a degree of local frustration with the second-hand critical culture, and one event brought this sharply to light. In November 1948 the N\&DFS banded together with the Leicester Film Society to hold a special joint screening of seven films (Programme for the Joint Meeting at Stanford Hall. November 27). Although some of the titles had been previously screened in Scotland at the Edinburgh Film Festival, ${ }^{7}$ it was proudly declared that four of these films were receiving 'their first showing in England.' For one film in particular, Lumière d'Été (France, Grémillion, 1942), the absence of prior critical opinion was actively celebrated.

This film has not been written up by any of the critics in the Press for the very good reason that it has been imported privately by the Federation [of Film Societies]. It is such a curious film, realistic in appearance, fantastic in mood, that it will be most interesting for viewers to decide whether it is a little masterpiece, or on the other hand, unintelligible dull nonsense-or in some intermediate class.

Here, the power to judge the film is being handed directly to the East Midlands viewers, and they are strongly encouraged to embrace it. The film had received enough attention in the specialist press to enable the broad classifications 'realistic' and 'fantastic' to be invoked. However, this did not diminish the programmers' delight that members would not have to match their views on the film against a pre-existing London based critical consensus. This time, the more detailed terrain of the debate had yet to be mapped, and it would be up to the Nottingham viewers to determine the grounds on which the film would be deemed a success or failure. 
Moreover, although the local programme writer did not explicitly refer to it, it seems likely that he knew exactly how neatly timed their booking of Lumière d'Été was. The N\&DFS were showing the film just three days in advance of its first London screening. This was to be held at the Scala by the New London Film Society: the prestigious group run by Olwen Vaughan, and the film society that many of the famous published critics routinely attended. ${ }^{8}$ This reversal of the usual booking priorities is at first glance surprising, but becomes less so in light of the fact that many of the key players within the Federation (including Cotterill, the secretary of the Leicester Film Society) were themselves based outside the capital. ${ }^{9}$

\section{Too Many Tragedies?}

When the planned screening date for Les Visiteurs du soir arrived in January 1949, the film print did not. In the preceding October, just a month after the Le Quai des brumes programme had promised the opportunity to compare and contrast, an amendment had to be issued, as the more recent title, Les Visiteurs $d u$ soir, had been booked for a public charity screening in Nottingham and was therefore no longer available to the film society (N\&DFS. 1948. Programme Notes, October 22). However, despite the frustration that such cancellations caused, the notes introducing the less prestigious film programmed as its replacement reveal that there may not have been complete appreciation for the procession of films deemed most worthy of attention by the critics.

This charming comedy replaces Les Visiteurs $d u$ soir which as members may recall was cancelled earlier this season. Some may regret the cancellation, but many will welcome the light relief from the rather grim tragedies which have featured in earlier programmes.

From the notes for La Cage aux rossignols (France, Dréville, 1945), (N\&DFS. 1949. Programme Notes, January 30).

This perhaps responded to one of the 1948/49 season request slips, which had concluded emphatically 'and not so many tragedies please!' (Nottingham County Archive, M12, 361/40). Moreover, the programmer himself had chosen to bring the issue into focus for members by signing off the programme note containing the request slip thus: 
This preoccupation with tragedy is typical of the French cinema of this period, indeed it is difficult to name a major pre-war film by any of the leading French Directors which in spite of varying back-ground or subject, does not dwell on the poetry of despair or insist on the fatalism of illusory happiness. (N\&DFS. 1948. Programme Notes, December 5).

A concentration of films that made a good focus for a published critical debate did not necessarily make a good season's film society programming. Although the films that had drawn the greatest critical buzz inevitably generated the greatest concentration of member requests, these did not account for the majority of the film preferences expressed within the N\&DFS. Members requested a wide range of films, old and new, light and serious, some comic but many of them falling somewhere on the subjective spectrum of emotion from tragic to touching. The problem was less the programming of 'grim tragedies' but rather if there seemed to be an absence of anything else. As the British Federation of Film Societies would acknowledge in their programming advice a few years later, there was often a conflict between received critical judgement and good programming practice. Despite that fact they claimed 'a high proportion of the finest films are tragic' the Federation warned societies against programming successive tragic films $(1961,14)$. Regardless of what London considered the most pressing topic for critical focus and evaluation, it was important that the film society principle of presenting a balanced programme should not be undermined.

At the end of the 1948/49 season seventy-eight members completed a questionnaire numbering the ten feature films screened that year in order of preference. This produced a local popularity listing running from first to last as follows: Vivere in Pace (Italy, Zampa, 1947), Panique (France, Duvivier, 1947), Farrebique (France, Rouquier, 1946), La Cage aux rossignols (France, Dreville, 1945), Enrico IV (Italy, Pastina, 1943), Le Quai des Brumes (France, Carne, 1938), Day of Wrath (Denmark, Dreyer, 1943), Kameradschaft (Germany, ${ }^{10}$ Pabst, 1931), The New Teacher (USSR, Gerasimov, 1939). Here it is possible to see a strong preference for the post-war titles, addressing humanist concerns in a range of aesthetic and emotional registers. In 1949, Nottingham viewers embraced both the documentary style of Farrebique and the more overt sentiment of La Cage aux rossignols, but viewed from the current perspective, the films that probably remain most prominent in the UK's international canon take places seven, eight and nine in 
the list.

The N\&DFS continued to screen comedies and the classics of earlier eras, and in 1951, following a relaxation of censorship, the programmer attempted to book the longer, less heavily cut version of La Kermesse héröque, which was about to be reissued. However, the endless delays associated with this booking served to highlight that the local society might have more in common with the London audience for foreign film than the specialist press did. The problem was caused by the spectacular London success of another risqué French title - La Ronde (France, Ophuls, 1950). The Kermesse hérö̈que reissue had been scheduled to follow La Ronde at The Curzon, but the new title was so successful it was held over at the venue well into a second year. ${ }^{11}$ Ultimately the older film found another spot for its London relaunch, but there was no question that it would be able to meet any provincial bookings until this had happened.

As had been the case at the time of the film's original 1936 release, London still had a healthy appetite for 'typically' French films: the witty, the risqué, the picaresque, and the sophisticated. Here, film societies like Nottingham were in a difficult position. As Elizabeth Harris stressed - rather critically - in her Penguin Film Review article on the role of the specialist cinema, film societies were supposed to have a higher, more educative purpose than simply re-screening the popular continental hits from London's West End $(1948,84)$. The expectation was that they should ape the more highbrow and earnest end of metropolitan taste, and the N\&DFS had certainly allied itself to the art and education agenda. However, whilst critics in London had a number of commercial cinemas where they could go to watch and perhaps disapprove of the less serious French titles, in provincial towns and cities the film society had to serve both audiences - those who wanted the most current and intellectually challenging highbrow experience and those who wanted something entertaining or touching with a sophisticated continental flavour. Film societies were able to accept that for that for many members there could be some happy overlap between the two. Moreover, certain films seemed to offer the chance to combine a sense of participating in a relevant critical debate with more straightforward pleasures. Where the expensive and elaborate period production of Les Enfants $d u$ paradis had left the London critics divided, the N\&DFS audience embraced it 
wholeheartedly, voting it the runaway winner of the 1949/50 season (Results of Questionnaire, NCA, M12, 363).

\section{Conclusion}

This study illustrates the waves of influence involved in framing the reception of foreign film, highlighting in particular, the way that messages about the meaning of national cinema become refracted by both national and local agendas in the country of reception. This process occurs at multiple levels. All sectors of Britain's 'serious' film culture looked to French sources of authority to define French cinema, whether directly or indirectly. However the spectrum of authentically French cinema experiences sought by London critics and Nottingham film society members differed in accordance with their particular aims and practical conditions of access.

Both at the national review level and at the level of local consumption, a large part of the established value of French films was derived from the distinctive ways in which they were not American. Within the specialist press, Occupation and post-war French cinema needed to be seen to be still uniquely French: an art form that could respond to national experience, and embody national culture and character by resisting the forces of Americanisation. However, it is notable that in pressing the case for realism, British writers were asking for a nationally specific variant of precisely the qualities they valued in British cinema, and in the emergent Italian neorealist scene.

Marcel Carné emerged as a key figure for a number of reasons: he had been considered the prime exponent of the French realist tradition before the war, and in not deserting France he had also chosen not to go to America (unlike Duvivier and other popular French directors). This too was part of a wider critical agenda in which any 'authentic' and 'cultural' national cinema was to be framed as a subset of a 'natural' international impulse towards the real, which in turn could be collectively defined in opposition to Hollywood's commercial fantasy. In this context, any perceived turn from the real was worrying; it had to be contextualised and ultimately corrected. Consequently, within the Penguin Film Review, authentically French writers were enlisted to chide the British readership to improve their tastes in French cinema and speed the process. Just as a highly selective representation of French 
national cinema had been proposed by the critics as an inspirational object for the British industry in the 1930s, in the post-war era, an equally selective version of new French cinema was being held up by the critics as ideal material for an alternative 'serious' model of film viewing, divorced from Hollywood and the passive mode of attention it was thought to inspire.

For those within the N\&DFS, part of the embrace of French culture was about demonstrating a visible cosmopolitanism within British culture, both as a mark of distinction on the local scene and as a bid for parity with London's cultured classes. Moreover, the smaller quantity and greater commercial viability of the new Italian releases worked to consolidate film society attention on French cinema and the discourses surrounding it. However, issues of access, availability, and appropriate choice of foreign films implicitly positioned the N\&DFS within a hierarchy of British specialist film culture. Failure to recognise the right sort of qualities in French films, and to reject the titles that lacked them, could risk the society being tainted by metropolitan accusations of middlebrow provincialism. Nonetheless, there was a genuine appetite for, and enjoyment of, a wide range of French titles in Nottingham. Moreover, the film society movement's principles of balanced programming acted as an alternate source of authority, legitimating the inclusion of lighter titles, and helping to leaven the dissemination and illustration of critical debates.

The N\&DFS worked hard to situate both fashionable and unfashionable French films within the debates, whether through the explanation of terminology, or through the use of slightly depreciating language. Through routine practices and processes of textual appropriation, the words and opinions of published writers were woven into the fabric of film society culture, reinforcing the critical voices members encountered in the wider public sphere. However, due to the extended absence of the films themselves, these critical voices may have resonated longer and louder within the provincial film society circuit than they did at their metropolitan point of origin. This perhaps accounts for the Nottingham programmers' somewhat ambivalent relationship to the constant stream of published opinion.

\section{References}

Acland, Charles. 1994. National dreams, international encounters: The formation of Canadian film culture in the 1930s. Canadian Journal of Film Studies 3, no 1: 
$3-26$.

Ackland, Rodney. 1946. New London Film Society: Annual Report, year ended 30 June (author's own collection).

Ackland, Rodney, and Elspeth Grant. 1954. The celluloid mistress; or, the custard pie of Dr. Caligari. London: Allan Wingate.

Andrew, Dudley. 2010. Time zones and jetlag: The flows and phases of world cinema. In World cinemas, transnational perspectives, ed. Natasa Durovicova and Kathleen Newman, 59-89. London and New York: Routledge.

Allen, Robert C, and Douglas Gomery. 1985. Film history: Theory and practice. 1st ed. McGraw-Hill Higher Education.

Barr, Mischa. 2009. Sex, art and sophistication: the meanings of 'Continental' cinema. Journal of Australian Studies 33, no 1: 1-18.

Betz, Mark. 2003. Art, exploitation, underground. In Defining cult movies: The cultural politics of oppositional taste, ed. Mark Jancovich, 202-222. Manchester: University of Manchester Press.

Birmingham Film Society. 1948. Flashback: A hundred shows of the Birmingham Film Society 1931-1948. Birmingham: Journal Printing Office.

Bordwell, David. 2002. The art cinema as a mode of film practice. In The European cinema reader, Catherine Fowler, 94-102. London: Routledge. Originally published in 1979. Film Criticism 4, no 1: 56-64.

Bolas, Terry. 2009. Screen education: From film appreciation to media studies. Bristol: Intellect Books.

Committee of the Federation of Film Societies 1961. Forming and running a film society, ed. J. R. Cottrill, rev. by Margaret Hancock, $3^{\text {rd }}$ edn. Leicester: Federation of Film Societies.

D.P. 1973. Olwen Vaughan: Film society pioneer. Obituaries, The Times, August 23.

Drazin, Charles. 1999. Olwen Vaughan and the French Club. London Magazine March, 67-76.

Dupin, Christophe. 2006. The postwar transformation of the British Film Institute. Screen 47, no 4: 443-451.

Dyer, Ernest. 1938. What do they like? Sight and Sound 7, no 26: 78-79.

Ellis, John. 1996. The quality film adventure: British critics and the cinema 19421948. Revised edn, in Dissolving views: Key writings on British cinema, ed. Andrew Higson, 66-93. London: Cassell.

Fowler, Roy. 1946. The film in France. London: Pendulum.

Fuller-Seeley, Kathryn, ed. 2008. Hollywood in the neighborhood: Historical case studies of local moviegoing. Berkeley, Los Angeles and London: University of California Press.

Gomery, Douglas. 1992. Shared pleasures: A history of movie presentation in the United States. Madison, Wis. and London: University of Wisconsin Press.

Grieveson, Lee, and Haidee Wasson, eds. 2008. Inventing film studies. Durham and London: Duke University Press.

Hackett, Hazel. 1946a. The French cinema during the Occupation. Sight and Sound 15, no 57: 1-3. 
- - - 1946b. The French cinema since the Liberation. Sight and Sound 15, no 56: 48-52.

Hagener, Malte. 2007. Moving forward, looking back: The European avant-garde and the invention of film culture 1919-1939. Amsterdam: Amsterdam University Press.

Harris, Elizabeth. 1948. The function of the specialized cinema. Penguin Film Review, no 7: 80-86.

Hogenkamp, Bert. 1986. Deadly Parallels: Film and the Left in Britain 1929-1939. London: Lawrence and Wishart.

Jancovich, Mark, with Lucy Faire and Sarah Stubbings. 2003. The Place of the Audience: Cultural Geographies of Film Consumption. London: British Film Institute.

Kracauer, Siegfried. 1947. From Caligari to Hitler: A psychological history of the German film. Princeton, N.J: Princeton University Press.

MacDonald, Richard. The vanguard of film appreciation: the film society movement and film culture, 1945-1965. In The British Film Institute: The government and film culture 1933-2007, ed. Geoffrey Nowell-Smith and Christophe Dupin, 87-101. Manchester: Manchester University Press.

Manvell, Roger. 1944. Film. Harmondsworth: Penguin.

Manvell, Roger. 1946. Marcel Carné. Sight and Sound 15, no 57: 4-6.

Marcus, Laura. 2007. The tenth muse: Writing about cinema in the modernist period. Oxford and New York: Oxford University Press.

Mazdon, Lucy. 2010. Vulgar, nasty and French: French cinema in Britain in the 1950s. Journal of British Cinema and Television 7, no 3: 421-438.

Munro, Emily. 2006. The language problem in European cinema: Discourses on "Foreign-Language Films" in criticism, theory and practice. PhD diss., University of Glasgow.

Nottingham and District Film Society. 1945-1959. Programme Notes and Ephemera. Held at Nottingham Local Studies Collection, Nottingham City Library. See in text citations for specific programme dates.

Nottingham and District Film Society. 1945-1959. Administrative Records. Held at Nottinghamshire County Archive. File numbers M12, 334-94. See in text citations for specific dates, details and file references.

Novik, William. 1947. Four years in a bottle: A critical study of French film production under the Occupation. Penguin Film Review, no 2: 45-53.

Polan, Dana B. 2007. Scenes of instruction: The beginnings of the U.S. study of film. Berkeley, Los Angeles and London: University of California Press.

Porter, Vincent. 2010. The exhibition, distribution and reception of French films in Great Britain during the 1930s. In Je t'aime... moi non plus: Franco-British cinematic relations, ed. Lucy Mazdon and Catherine Wheatley, 19-36. New York and Oxford: Berghahn.

Rose, Felix. 1937. The Cinema in France 1936. Sight and Sound, 6, no 22: 71-74.

Selfe, Melanie. 2007. Doing 'the work of the NFT in Nottingham' or How to use the BFI to beat the Communist threat in your local film society. Journal of British 
Cinema and Televsion 4, no 1: 80-101.

Selfe, Melanie. 2012. The view from outside London: the centre and the regions 1960-1980. In The British Film Institute: The government and film culture 1933-2007, ed. Geoffrey Nowell-Smith and Christophe Dupin, 116-132. Manchester: Manchester University Press.

Sexton, Jamie. 2008. Alternative film culture in inter-war Britain. Exeter: University of Exeter Press.

Sight and Sound. 1950. Film Society Notes. 19, no 6: 263.

Staiger, Janet. 1992. Interpreting films: Studies in the historical reception of American Cinema. New Jersey: Princeton University Press.

Street, Sarah. 2002. Transatlantic Crossings: British Feature Films in the USA. New York and London: Continuum.

Vedrès, Nicole. 1946. The French cinema since 1944. Penguin Film Review, no 1: 7479.

Waller, Gregory A. 1995. Main Street amusements: Movies and commercial entertainment in a southern city, 1896-1930. Washington: Smithsonian Books.

Wasson, Haidee. 2005. Museum movies: the museum of modern art and the birth of art cinema. Berkeley, Los Angeles and London: University of California Press.

Wilinsky, Barbara. 2001. Sure seaters: The emergence of art house cinema. Minneapolis: University of Minnesota Press.

Wimmer, Leila. 2009. Cross-channel perspectives: The French reception of British cinema. Oxford, Bern and New York: Peter Berg.

\section{Notes}

${ }^{1}$ Collated from BFI Annual Report accounts of British Federation of Film Societies figures.

${ }^{2}$ Mazdon's larger project considers the longer history of British reception of French film, but this initial article shares many features with the exhibition-centred studies listed.

${ }^{3}$ An incomplete collection of Birmingham Film Society materials is held by the BFI, in Special Collections. In 1952, the BFI started issuing a monthly critical round-up pamphlet called Critics' Choice to members, echoing the provincial film society practice.

${ }^{4}$ The Times reported a prestigious crowd for the film's British premier held at Studio One on the 16 October 1936, and it ran there until the 7 May 1937. It returned to London in the autumn of 1937, playing short runs at a succession of cinemas: the Berkeley (October), the Everyman (January 1938) and the Forum (January/February 1938), before being screened by BBC in October of 1938. Its progress can be tracked through the advertising and broadcasting listings of The Times.

${ }^{5}$ These are collected in NCA, M12, 361.

${ }^{6}$ This was one of the titles most commonly requested in 1948 for the 1949/50 season (ten members), NCA, M12, 361. 
${ }^{7}$ This was founded in 1947 by one of the older film societies, the Edinburgh Film Guild, and building upon the wartime writings of organisers, Forsyth Hardy and Norman Wilson, it helped to consolidate Edinburgh as a competing node of film culture authority and leadership within the British film society movement.

${ }^{8}$ New London Film Society, The programme notes for the final show of the 19471948 Season (9 May 1948) include advance notice of the screening of Lumière d'Été to be held on the 30 November 1948 (author's own collection). As Drazin notes, both Dilys Powell and Richard Winnington were not only members of the society, they also promoted the NLFS in their columns. His assertion that their screening of Lumière d'Été was one of a series of British premieres organised by Vaughan does not seem to be supported by the records of the respective Stanford Hall and Scala exhibition dates, but he may be right in claiming that the director Jean Gremillion flew in from Paris to attend the London screening. (1999, 74).

${ }^{9}$ Vincent Porter notes a precedent for this in 1938, when a Jim Fairfax-Jones arranged a screening of La Kermesse héroïque at the Southampton society, the day before his own cinema, the Everyman in Hampstead, was due to revive it $(2010,25)$.

${ }^{10}$ Although a German and French co-production, this was billed to members as a German film.

${ }^{11}$ The run lasted from April 1951 to October 1952, before moving to the Berkeley, The Times. 1951. April 23; The Times. 1953. October 10. 